\title{
GENETIC DIVERSITY OF INDIGENOUS COMMON BEAN (PHASEOLUS VULGARIS L.) RHIZOBIA FROM THE STATE OF MINAS GERAIS, BRAZIL
}

\author{
Adalgisa Ribeiro Torres¹; Luciana Cursino²; Júpiter Israel Muro-Abad ${ }^{3}$; Eliane Aparecida Gomes ${ }^{4}$; Elza Fernandes de \\ Araújo $^{1}$; Mariangela Hungria ${ }^{5 *}$; Sérvio Túlio Alves Cassini ${ }^{6}$ \\ ${ }^{1}$ Departamento de Microbiologia, Universidade Federal de Viçosa, Viçosa, MG, Brasil; ${ }^{2}$ Department of Plant Pathology and \\ Plant-Microbe Interaction, Cornell University, New York State Agriculture Experimental Station, Geneva, New York, USA; \\ ${ }^{3}$ Aracruz Celulose S.A., Centro de Pesquisa e Tecnologia, Aracruz, ES, Brasil; ${ }^{4}$ Embrapa Milho e Sorgo, Sete Lagoas, MG, \\ Brasil; ${ }^{5}$ Embrapa Soja, Londrina, PR, Brasil; ${ }^{6}$ Departamento de Engenharia Ambiental, Centro Tecnológico, Universidade \\ Federal do Espírito Santo, Vitória, ES, Brasil.
}

Submitted: August 13, 2008; Returned to authors for corrections: January 27, 2009; Approved: June 28, 2009.

\begin{abstract}
We characterized indigenous common bean rhizobia from five districts of the state of Minas Gerais, Brazil. The isolates were trapped by two common bean varieties, the Mineiro Precoce (Andean origin) and Ouro Negro (Mesoamerican origin). Analysis by BOX-PCR of selected isolates detected a high level of genetic diversity.
\end{abstract}

Key words: BOX-PCR; Phaseolus vulgaris; Rhizobium.

Commom bean (Phaseolus vulgaris L.) grains represent the most important source of protein, especially for lowincome people in Latin America, and also in South and West Africa. Mesoamerica and Andean South America are considered the main centers of genetic origin and/or domestication of P. vulgaris (6), but the legume has been widely grown in Brazil for thousands of years. Nowadays, Brazil is the largest grower and consumer of common beans worldwide, but national mean yields are low, estimated at $817 \mathrm{~kg} \mathrm{ha}^{-1}$ in the last crop season (4).

An important aspect of this crop is its capacity of establishing symbiotic associations with rhizobial species capable of nodulating and in most cases fixing atmospheric nitrogen $\left(\mathrm{N}_{2}\right)$. However, most of the symbiotic interactions are not effective (13). Studies performed in this last decade have shown that the selection of effective strains adapted to local environmental conditions may represent a successful approach that should be pursued (8). Nevertheless, it is also very important to assess the genetic diversity of indigenous rhizobial communities within the main producing areas, as the composition of the local community can affect the response to inoculation with superior strains. Unfortunately, knowledge of the genetic diversity of indigenous common bean rhizobia in most Brazilian ecosystems is still very poor. 
This study aimed at evaluating the genetic diversity of indigenous common bean rhizobia from the state of Minas Gerais, one of the most traditional states in growing this legume in Brazil. We selected BOX-PCR as the molecular typing technique due its reproducibility, easiness, quickness, and high discriminatory power at the strain level (14), yielding results that may give a good correlation with pairwise DNA-DNA analyses (16).

Strains representative of described rhizobial genera/species capable of nodulating common bean were used for comparison. The following strains were provided by Dr. P. van Berkum (USDA, Beltsville, MD, USA): Sinorhizobium meliloti USDA $1002^{\mathrm{T}}$ (=ATCC 9930, =LMG 6133, =3DOa2); Rhizobium leguminosarum bv. trifolii USDA 2145 (=ATCC 14480, =LMG 8820, =3DIK22a); $R$. leguminosarum bv. phaseoli USDA 2671 (=RCR 3644); Bradyrhizobium japonicum USDA 94; Mesorhizobium loti NZP $2213^{\mathrm{T}}$ (=ATCC 33669, =LMG 6125, =USDA 3471); $M$. ciceri USDA 3383; S. fredii USDA $205^{\mathrm{T}}$ (=ATCC 35423, $=\mathrm{LMG}$ 6217, =PRC 205). Dr. E. Martínez, Cuernavaca, Mexico sent the strains $R$. tropici type A CFN 299 (=USDA 9039, =LMG 9517), type B CIAT $899^{\mathrm{T}}$ (=UMR 1899, $=$ USDA 9030, =TAL 1797, =HAMBI 1163, =SEMIA 4077, $=$ ATCC 49672) and $R$. etli bv. phaseoli CFN $42^{\mathrm{T}}$ (=USDA 9032). Dr. Noelle Amarger (INRA, Dijon, France) sent the strain $\mathrm{H} 152^{\mathrm{T}}$ of $R$. giardinii bv. giardinii.

Soil samples were collected from five different areas in the state of Minas Gerais, Brazil (Table 1) from the 0-20 cm layer, with a soil corer that was cleaned with alcohol (95\%) and flamed between samplings. Two bean varieties from contrasting centers of genetic origin were used as trap host: Mineiro Precoce (Andean region, beige seeds) and Ouro Negro (Mesoamerican region, black seeds), both previously reported as good hosts for $\mathrm{N}_{2}$-fixing bacteria (5). Seeds were surface-disinfested according to Vincent (1970) and pregerminated at $28^{\circ} \mathrm{C}$ in Petri dishes containing sterile $0.5 \%$ $(w / v)$ agar in water. Seedlings were then transplanted to vases containing $500 \mathrm{~g}$ of each soil sample. Plants were grown under greenhouse conditions at $28 / 22^{\circ} \mathrm{C}$ (day/night) and received $\mathrm{N}$-free nutrient solution (3). After four weeks, the rhizobia were isolated on yeast extract-mannitol agar (YMA) medium (21), from fresh root nodules. The experiment was set up as a randomized complete block design with 3 replicates for each treatment.

The rhizobia were isolated from fresh root nodules on YMA medium. The purity of the rhizobial cultures was confirmed by repeatedly streaking the bacteria on YMA medium and by determining colony morphology, Congo red absorption $(25 \mathrm{mg} / \mathrm{ml})$, and acid/alkali production on YMA containing $0.01 \%$ bromothymol blue (1). Each colony was then transferred to YM liquid broth (YMB), and after further growth, the bacteria were dried on porcelain beads and stored at $4^{\circ} \mathrm{C}$, as described by Hunt et al. (10). Working cultures were maintained on YMA slants at $4{ }^{\circ} \mathrm{C}$.

Table 1. Localization and relevant soil management of the sites in the state of Minas Gerais, Brazil, used in this study

\begin{tabular}{llll}
\hline No & Site & Geographic coordinates & Soil management \\
\hline 1 & Capinópolis & $18^{\circ} 41^{\prime} \mathrm{S}$ & Cropped with common beans \\
& & $49^{\circ} 38^{\prime} \mathrm{W}$ & \\
2 & Janaúba & $15^{\circ} 47^{\prime} \mathrm{S}$ & Cropped with common beans \\
& & & \\
3 & Maria da Fé & $23^{\circ} 18^{\circ} \mathrm{\prime} 7^{\prime} \mathrm{W}$ & Cropped with common beans \\
& & $45^{\circ} 23^{\prime} \mathrm{W}$ & \\
4 & Patos de Minas & $18^{\circ} 36^{\prime} \mathrm{S}$ & Cropped with common beans \\
& & $46^{\circ} 31^{\prime} \mathrm{W}$ & \\
$5 \mathrm{~A}$ & Viçosa & $20^{\circ} 45^{\prime} \mathrm{S}$ & Cropped with common beans \\
& & $42^{\circ} 51^{\prime} \mathrm{W}$ & \\
$5 \mathrm{~B}$ & Viçosa & $20^{\circ} 45^{\prime} \mathrm{S}$ & Undisturbed area covered with native \\
& & $42^{\circ} 51^{\prime} \mathrm{W}$ & vegetation \\
\hline
\end{tabular}


Twenty isolates trapped by both varieties, Ouro Negro and Mineiro Precoce, were randomly selected for BOX PCR analysis: 4 from Viçosa, 3 from Janaúba, 4 from Maria da Fé, 5 from Patos de Minas, and 4 from Capinópolis. Rhizobial DNA was extracted as described by Ausubel et al. (2). PCR amplification was carried out with BOX A1R (5'CTACGGCAAGGCGACGCTGACG-3') primer (Invitrogen), following the procedure described by Versalovic et al. (20). The fingerprints obtained in PCR procedures were analyzed using BioNumerics software (Applied Mathematics, Kortrijk, Belgium, version 4.6), with the UPGMA algorithm [unweighted pair-group method with arithmetic mean, (18) and Jaccard coefficient (J) (11)]. The genetic diversity of the rhizobial communities was estimated using the Shannon diversity index:

$$
H=-\sum_{i=1}^{n}\left(\left(\frac{x_{i}}{x_{0}}\right) \ln \left(\frac{x_{i}}{x_{0}}\right)\right) \quad(17), \text { where } H \text { is the }
$$

genetic diversity, $x_{i}$ the number of isolates in each group, and $\mathrm{x}_{0}$ the total number of isolates.

Some previous studies have examined the diversity of rhizobia associated with common bean in different producing areas of Brazil $(8,12,15)$. Although a great diversity in morphological, physiological, genetic and symbiotic properties has been found among common bean rhizobial strains from Brazil, there are few reports (19) on genetic variability among indigenous rhizobia from the state of Minas Gerais.

We obtained 77 indigenous rhizobial isolates in this study: 33 from Capinópolis, 8 from Janaúba, 4 from Maria da Fé, 22 from Patos de Minas and 10 from Viçosa. The Mineiro Precoce variety trapped $58 \%$ of the isolates, while Ouro Negro trapped $42 \%$. In the soils of Janaúba, Patos de Minas and Viçosa, the ability to trap indigenous common bean rhizobia was similar for both varieties. However, variety Mineiro Precoce was more effective in trapping rhizobia from Capinópolis, while Ouro Negro showed a better performance with Maria da Fé (data not shown).
It is well known that common bean seeds contain a variety of flavonoids related to the seed color, responsible for the rhizobial nod-gene inducing activity and that may affect nodulation (9). However, in our study there is no recognizable effect of either the variety or the sampling site on rhizobial diversity. In another study using ERIC-PCR, Grange and Hungria (7) also did not detect differences between black- or beige-seeded common beans in their capacity to trap rhizobia from the soils of two other Brazilian states, Paraná and Pernambuco.

All isolates produced a single morphologically homogeneous group of colonies, which were white, displayed fast growth (three days), and had a high exopolysaccharide production and acidic changes in growth culture medium.

A high level of polymorphism was observed in the BOXPCR analysis, as in the clustering analysis using the UPGMA algorithm and the Jaccard coefficient, the profiles were joined at a very low final level of genetic similarity, of only $10 \%$ (Fig. 1). Four rhizobial groups were clearly observed. Group 1 clustered 8 isolates and $M$. loti reference strain USDA 3471 with $27 \%$ similarity and could be split into 2 subgroups, in addition to a single isolate [21] trapped by Mineiro Precoce grown on a Capinópolis soil. This group included isolates from Capinópolis, trapped by both varieties and isolates from Viçosa, trapped by Ouro Negro. Group 2 included 12 isolates and the $R$. tropici type A reference strain CFN 299, at a $32 \%$ level of similarity. However, the analysis showed that the isolates were different from the $R$. tropici type $\mathrm{B}$ reference strain CIAT 899. Within this group, some isolates displayed complete similarity, e.g., isolates 10,11, 12 and 13, and 7 and 14. Three of these isolates [11, 12 and 13] were trapped by Ouro Negro grown in Maria da Fé and Patos de Minas soils. Only one of these isolates [10] which exhibited complete profile similarity was isolated from Mineiro Precoce plants grown in soil samples of Maria da Fé. It is noteworthy that two isolates within group $2[7,14]$ showed complete similarity of profiles although isolated from different sample locations. Groups 3 and 4 clustered only type and reference strains at $29 \%$ and $38 \%$ similarity, respectively. It should also 
be mentioned that within group 2, some isolates differed only by one or two bands, e. g., isolates 6, 7, 9 and 14. Finally, isolate 8 from Janaúba, trapped by Mineiro Precoce, was quite distinct from all groups. None of the isolates in this study clustered with Azorhizobium caulinodans,
Bradyrhizobium japonicum, B. liaoningense, Mesorhizobium ciceri, Rhizobium etli bv. phaseoli and $R$. giardinii bv. giardinii, R. leguminosarum bv. phaseoli, R. leguminosarum bv. trifolii, R. tropici type B, Sinorhizobium (=Ensifer) fredii or S. meliloti.
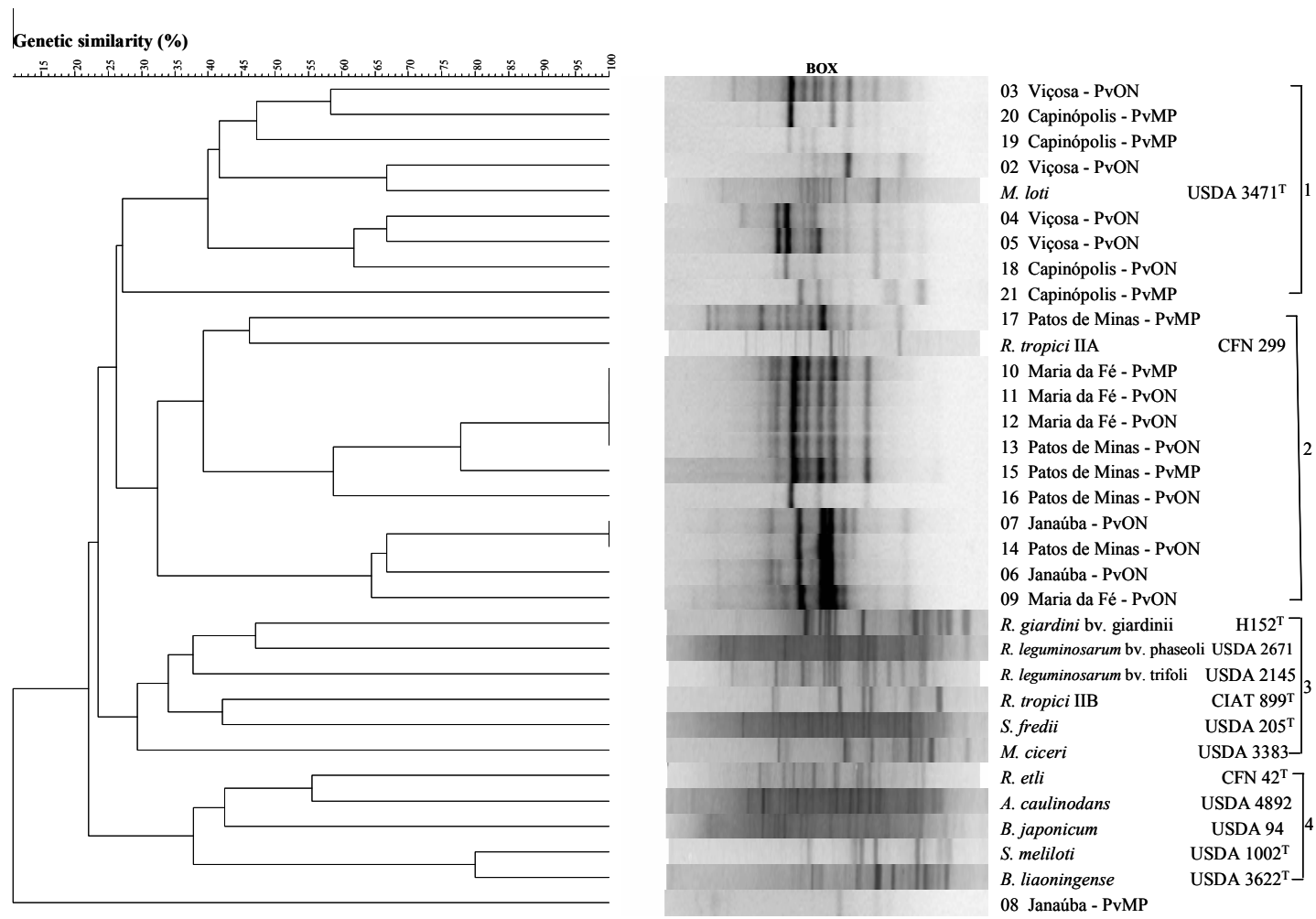

Figure 1. Dendrogram showing the bean rhizobial isolates from the state of Minas Gerais and some reference and type strains used in this study after cluster analysis of BOX-PCR products using the UPGMA method and the Jaccard coefficient. PvONPhaseolus vulgaris cv. Ouro Negro; PvMP- Phaseolus vulgaris cv. Mineiro Precoce.

Despite the high polymorphism observed with BOX primer, diversity index $(H)$ was slightly higher in Janaúba, Maria da Fé and Patos de Minas (0.37) than in Capinópolis and Viçosa (0.35). Indeed, in our study, the genetic characterization using BOX-PCR was very effective for differentiating the isolates.

Indigenous bean rhizobia can be recovered from both uncropped and cropped soils in Brazil (7). In this study, none of the areas had a previous history of inoculation with rhizobia, thus the strains obtained represent the indigenous diversity.

It would now be important to perform long-term field trials with these isolates to establish strategies towards increasing the contribution of the biological $\mathrm{N}_{2}$ fixation to the common bean $\mathrm{N}$ nutrition and to find inoculants to specific locations of Minas Gerais. 


\section{REFERENCES}

1. Araujo, R.S. (1994). Fixação biológica do nitrogênio em feijão. In: Araújo, R.S., Hungria, M. (eds). Microrganismos de importância agrícola. EMBRAPA, Brasília, p. 91-112.

2. Ausubel, F.M.; Brent, R.; Kingston, R.E.; Moore, D.D.; Seidman, J.G.; Smith, J.A.; Struhl, K. (1992). Current Protocols in Molecular Biology, New York: Greene Publishing Associates and Wiley-Interscience.

3. Centro Internacional de Agricultura Tropical (1985). Evaluación, selección y manejo de sistemas leguminosa-rhizobio para aumentar la fijación de nitrógeno. Cali, Colômbia

4. CONAB (Companhia Nacional de Abastecimento). Feijão total $\left(1^{\circ}, 2^{\mathrm{a}} \mathrm{e}\right.$ $3^{\text {a }}$ safra) - Acompanhamento da safra brasileira: grãos: oitavo levantamento, maio 2008. Available at: http://www.conab.gov.br/conabweb/download/safra/estudo_safra.pdf. Accessed 14 May 2008.

5. Gavilanes, M.L.; Santos, J.B. (1998). Botânica. In: Borém, A., Paula Júnior, T.J., Vieira C. (eds) Feijão: aspectos gerais e cultura no estado de Minas. UFV, Viçosa, p 55-79.

6. Gepts, P. (1990). Biochemical evidence bearing on the domestication of Phaseolus (Fabaceae) beans. Econ Bot. 44, 28-38.

7. Grange, L.; Hungria, M. (2004). Genetic diversity of indigenous common bean (Phaseolus vulgaris) rhizobia in two Brazilian ecosystems. Soil Biol Biochem. 36, 1389-1398.

8. Hungria, M.; Andrade, D.S.; Chueire, L.M.O.; Probanza, A.; Guttierrez-Mañero, F.J.; Megías, M. (2000). Isolation and characterization of new efficient and competitive bean (Phaseolus vulgaris L.) rhizobia from Brazil. Soil Biol. Biochem., 32, 1515-1528.

9. Hungria, M.; Phillips, D.D. (1993). Effects of a seed color mutation on rhizobial nod-gene-inducing flavonoids and nodulation in common bean. Mol Plant-Microbe Interact. 6, 418-422.

10. Hunt, G.A.; Gourevitch, A.; Lein, J. (1958). Preservation of cultures by drying on porcelain beads. $J$ Bacteriol. 76, 453-454.

11. Jaccard, P. (1908). Nouvelles recherches sur la distribution florale. Bul
Soc Vaudoise Sci Nat. 44, 223-270.

12. Kaschuk, G.; Hungria, M.; Santos, J.C.P.; Berton-Junior, J.F. (2006). Differences in common bean rhizobial populations associated with soil tillage management in Southern Brazil. Soil Till Res. 87, 205-217.

13. Michiels, J.; Dombrecht, B.; Vermeiren, N.; Xi, C.; Luyten, E.; Vanderleyden, J. (1998). Phaseolus vulgaris is a non-selective host for nodulation. FEMS Microbiol Ecol. 26, 193-205.

14. Olive, D.M.; Bean, P. (1999). Principles and applications of methods for DNA-based typing of microbial organisms. J Clin Microbiol. 37, 1661-1669.

15. Oliveira, I.A.; Vasconcellos, M.J.; Seldin, L.; Paiva, E.; Vargas, M.A.; de Sá, N.M.H. (2000) Random Amplified Polymorphic DNA analysis of effective Rhizobium sp. associated with beans cultivated in Brazilian cerrado soils. Braz J Microbiol 31, 39-44.

16. Rademaker, J.L.W.; Hoste, B.; Louws, F.J.; Kerters, K.; Swings, J.; Vauterin, L.; Vauterin, P.; De Bruijn, F.J. (2000). Comparison of AFLP and rep-PCR genomic fingerprints with DNA-DNA homology studies: Xanthomonas as a model system. Int J Syst Evolut Microbiol. 50, 665677.

17. Shannon, C.E.; Weaver, W. (1949). The Mathematical Theory of Communication. University Illinois Press, Urbana.

18. Sneath, P.H.A.; Sokal, R.R. (1973). Numerical taxonomy. W.H. Freeman and Company, San Francisco.

19. Soares, A.L.L.; Ferreira, P.A.A.; Pereira, J.P.A.R.; do Vale, H.M.M.; Lima, A.S.; Andrade, M.J.B.; Moreira, F.M.S. (2006). Eficiência agronômica de rizóbios selecionados e diversidade de populações nativas nodulíferas em Perdões (MG). II - Feijoeiro. Rev Bras Ciên Solo. 30, 803-811.

20. Versalovic, J.; Schneider, M.; de Bruijn, F.J.; Lupski, J.R. (1994). Genomic fingerprinting of bacteria using repetitive sequence-based polymerase chain reaction. Meth. Mol. Cell. Biol., 5, 25-40.

21. Vincent, J.M. (1970). A Manual for the Practical Study of Root Nodule Bacteria, IBP Handbook No. 15. Blackwell Scientific Publications, Oxford, U.K. 